\title{
Pengaruh Ukuran Perusahaan, Pertumbuhan Penjualan dan Risiko Bisnis Pada Struktur Modal
}

\author{
Putu Meilita Halim ${ }^{1}$ \\ A.A.G.P. Widanaputra ${ }^{2}$ \\ ${ }^{1}$ Fakultas Ekonomi dan Bisnis Universitas Udayana (Unud), Bali, Indonesia \\ email: meilitah96@gmail.com/ Tlp: +6287865480387 \\ ${ }^{2}$ Fakultas Ekonomi dan Bisnis Universitas Udayana (Unud), Bali, Indonesia
}

\begin{abstract}
ABSTRAK
Struktur modal memiliki pengaruh yang sangat besar terhadap nilai perusahaan. Untuk mengetahui pengaruhnya di perhatikan faktor seperti Ukuran perusahaan, Pertumbuhan penjualan dan Risiko Bisnis. Tujuan penelitian ini adalah untuk menganalisis pengaruh ukuran perusahaan pada struktur modal, untuk menganalisis pengaruh pertumbuhan penjualan pada struktur modal dan untuk menganalisis pengaruh risiko bisnis pada struktur modal. Populasi dalam penelitian ini 13 perusahaan dengan menggunakan metode Purposive Samplin sampel penelitian ini 12 perusahaan. Penelitian ini dilakukan pada sektor industri otomotif terdaftar di Bursa Efek Indonesia pada periode 2014-2016 dengan teknik analisis regresi berganda. Melalui hasil pengolahan data maka dapat dikemukakan bahwa ukuran perusahaan tidak berpengaruh pada struktur modal, pertumbuhan penjualan berpengaruh positif pada struktur modal dan risiko bisnis berpengaruh negarif pada struktur modal perusahaan.
\end{abstract}

Kata kunci: Ukuran perusahaan, pertumbuhan penjualan, risiko bisnis dan struktur modal

\section{ABSTRACT}

Capital structure has a very big influence on the value of the company. To find out affect of capital structure, it is necessary to contcent factors such as firm size, sales growth and business risk. The purpose is analyze the effect of firm size on capital structure, to analyze the effect of sales growth and business risk on capital. The population in this study 13 companies using Purposive Samplin method of this research sample 12 companies. This research was carried out on the automotive industry sector admitted on the Indonesia Stock Exchange in the period 2014-2016 with multiple regression linier analysis techniques.Based on the results of data analysis it can be argued that the size of the company does not affect the capital structure, sales growth positively affect the capital structure and business risk negarif influence on the capital structure of the company.

Keywords: firm size, sales growth, business risk, and capital structure

\section{PENDAHULUAN}

Pentingnya struktur modal bagi perusahaan amat besar terhadap keuangan perusahaan serta nilai perusahaan, sehingga manajer keuangan harus memahami faktor yang mempengaruhi struktur modal agar dapat memaksimalkan kemakmuran pemegang saham perusahaan (Yuliati, 2013). Seseorang manajer keuangan diharapkan mampu mengambil keputusan dalam memilih sumber dana 
yang didapatkan serta seberapa besar dana itu digunakan oleh perusahaan agar nantinya dana yang diperoleh perusahaan tidak akan memberatkan perusahaan. Seorang manajer keuangan juga harus mampu mengetahui bagaimana dana tersebut harus digunakan dengan efisien, sehingga keputusan yang diambilnya nanti dapat meningkatkan profitabilitas dari perusahaan. Brigham dan Houston (2011) mengemukakan Pecking Order Theory perusahaan mengutamakan pendanaan dari dalam perusahaan. Trade Off Theory yang menyatakan suatu perusahaan memiliki tingkat utang yang optimal dan berusaha untuk menyesuaikan tingkat utang aktualnya kearah titik optimal, ketika perusahaan berada pada tingkat utang terlalu tinggi atau terlalu rendah Brigham dan Ehrhardt (2005).

Struktur modal dipengaruhi berbagai faktor eksternal perusahaan dan di dalam perusahaan. Faktor Eksternal perusahaan meliputi kondisi pasar modal, tingkat bunga, dan stabilitas politik sedangkan faktor internal perusahaan seperti profitabilitas perusahaan, ukuran perusahaan dan stabilitas dividen (Yusofi, 2016). Stabilitas penjualan, struktur aktiva, leverage operasi, risiko bisnis, tingkat pertumbuhan penjualan, profitabilitas, pajak, pengendalian, sikap manajemen, ukuran perusahaan dan fleksibelitas keuangan merupakan faktor yang mempengaruhi struktur modal (Brigham dan Houston. 2011). Ketika seseorang akan menginvestasikan modalnya pada suatu perusahaan maka mereka terlebih dahulu melihat kondisi perusahaan tersebut, apakah investasi yang akan dilakukan akan menghasilkan keuntungan yang diharapkan atau tidak. 
Hasil penelitian ini menyatakan bahwa kepemilikan dan profitabilitas berpengaruh pada struktur modal. Penelitian mengenai struktur modal juga dilakukan oleh Fitri (2013) “Determinants of Indonesian Firm's Capital Structure: Panel Data Analyses". menunjukan variabel tangibility, pertumbuhan penjualan, dan profitabiltas mempengaruhi pada struktur modal. Berikut ini adalah hasil penelitian terdahulu yang mengalami ketidakkonsistensian dalam penelitian yang dapat dilihat pada tabel 1.

Tabel 1.

Penelitian yang tidak konsisten

\begin{tabular}{|c|c|c|}
\hline $\begin{array}{l}\text { Variabel yang } \\
\text { diteliti }\end{array}$ & Peneliti & Hasil Penelitian \\
\hline $\begin{array}{c}\text { Ukuran } \\
\text { Perusahaan }\end{array}$ & $\begin{array}{l}\text { Awan (2011) dan Liem } \\
\text { (2013) } \\
\text { Yuke dan Hadri (2005) dan } \\
\text { Kartini dan Tulus (2008) } \\
\text { Laili Hidayati, et al (2001) }\end{array}$ & $\begin{array}{l}\text { ukuran perusahaan tidak } \\
\text { mempengaruhi struktur modal } \\
\text { ukuran perusahaan mempengaruhi } \\
\text { secara positif struktur modal } \\
\text { ukuran perusahaan mempengaruhi } \\
\text { secara negatif strukur modal }\end{array}$ \\
\hline $\begin{array}{l}\text { Pertumbuhan } \\
\text { Penjualan }\end{array}$ & $\begin{array}{l}\text { Winahyuningsih,.et al, } \\
\text { (2011) }\end{array}$ & $\begin{array}{l}\text { pertumbuhan penjualan } \\
\text { berpengaruh negatif pada struktur } \\
\text { modal } \\
\text { menunjukan tingkat pertumbuhan } \\
\text { penjualan berpengaruh positif } \\
\text { pada struktur modal. }\end{array}$ \\
\hline \multirow{3}{*}{ Risiko Bisnis } & $\begin{array}{l}\text { Saidi } \quad(2004) \quad \text { dan } \\
\text { Mutaminah (2003) }\end{array}$ & $\begin{array}{l}\text { Risiko Bisnis mempengaruhi } \\
\text { secara negatif pada struktur modal }\end{array}$ \\
\hline & $\begin{array}{l}\text { Crutcley dan Hansen } \\
(1989),\end{array}$ & $\begin{array}{l}\text { risiko bisnis mempengaruhi } \\
\text { secara positif dengan struktur } \\
\text { modal }\end{array}$ \\
\hline & Joni dan Lina (2012) & $\begin{array}{l}\text { Risiko bisnis tidak mempengaruhi } \\
\text { struktur modal. }\end{array}$ \\
\hline
\end{tabular}


Berdasarkan tabel 1 maka 3 variabel inilah yang di teliti oleh peneliti. Ukuran perusahaan adalah faktor pertama dalam penelitian ini. Ukuran perusahaan mencerminkan total aset dari perusahaan. Semakin besar ukuran perusahaan maka semakin mudah pula perusahaan mendapatkan tambahan modal dari internal maupun eksternal dan semakin kecil ukuran perusahaan maka semakin sulit pula perusahaan mendapatkan tambahan modal (Kartika, 2009), karena besar kecilnya perusahaan menggambarkan kepercayaan pihak dalam ataupun luar dalam melakukan pendanaan. Ukuran perusahaan menjadi acuan seseorang investor untuk menanamkan modalnya.

Pasar otomotif Indonesia merupakan pasar mobil terbesar di ASEAN yang menguasai hampir sepertiga total penjualan mobil tahunan ASEAN. Pasca krisis global pada tahun 2008, terjadi penurunan penjualan sebesar 20 persen pada tahun 2009 di angka 483.550 unit. Kemudian terjadi peningkatan penjualan selama empat tahun berturtut-turut yaitu pada tahun 2010 sampai dengan tahun 2013.Pada tahun 2010 penjualan mobil di Indonesia berada pada angka 764,710 unit meningkat 58 persen dibandingkan dengan tahun sebelumnya, pada tahun 2011 penjualan meningkat 17 persen pada angka 894.194 unit, pada tahun 2012 merupakan tahun pertama penjualan mobil di Indonesia mencapai angka satu juta unit dan meningkat sebesar 25 persen yaitu sebesar 1.116 .230 unit dan pada tahun 2013 penjualan mobil di Indonesia meningkat sebesar 10 persen pada angka 1.229.901 unit (www.idx.co.id). Berikut ini merupakan perkembangan industri otomotif wilayah ASEAN yang dapat dilihat pada tabel 2. 
Tabel 2.

\section{Pertumbuhan Penjualan Industri Otomotif di Wilayah ASEAN Tahun 2014-2016}

\begin{tabular}{lccc}
\multicolumn{4}{c}{ (dalam miliyar rupiah) } \\
\hline Negara & 2014 & 2015 & 2016 \\
Thailand & 881,832 & 799,632 & 768,788 \\
Indonesia & $1,208,019$ & $1,013,291$ & $1,061,735$ \\
Malaysia & 666,465 & 666,674 & 580,124 \\
Philippines & 234,747 & 288,609 & 359,572 \\
Vietnam & 133,588 & 209,267 & 270,820 \\
Singapore & 47,443 & 78,609 & 110,455 \\
Brunei & 18,114 & 14,406 & 13,248 \\
\hline ASEAN & $3,190,208$ & $3,070,488$ & $3,164,742$ \\
\hline
\end{tabular}

Tabel 2. menunjukan perkembangan pertumbuhan penjualan di bidang industri otomotif pada wilayah ASEAN, tahun 2014 Indonesia mengalami penurunan untuk pertama kalinya setelah mengalami pertumbuhan berturut-turut selama empat tahun yaitu sebesar 2 persen, namun pada tahun yang sama Indonesia sebagai pasar otomotif terbesar di ASEAN karena meraih posisi pertama sebagai penjualan mobil tertinggi dibandingkan wilayah ASEAN lainnya yaitu 1.208.019 unit, sedangkan dengan Brunei 18.114 unit mobil, Malaysia 666.465 unit, Filipina 234.747 unit, Singapura 47.443 unit, Thailand 881.832 unit dan Vietnam 133.566 unit. Menurunnya penjualan mobil Indonesia pada tahun 2014 diakibatkan oleh adanya beberapa kebijakan pemerintah terkait pertumbuhan ekonomi yang menyebabkan masyarakat harus berpikir lebih cermat lagi dalam membeli barang mahal (www.investasi-investment.com). Hal yang sama dialami pada tahun 2015, penjualan mobil di Indonesia mengalami penurunan sebesar 16 persen pada angka 1.013.291 unit kemudian mengalami peningkatan sebesar 5 persen pada angka1.061.735 unit di tahun 2016. Meskipun mengalami pertumbuhan penjualan yang berfluktuasi di tahun 2014-2016, tetapi Indonesia tetap menempati posisi pertama sebagai penjual mobil tertinggi di ASEAN. Maka 
dari itu peneliti tertarik untuk meneliti struktur modal yang dialami pada industri otomotif dengan penurunan pertumuhan penjualan yang dialami.

Melihat fenomena yang terjadi disertai hasil penelitian tidak konsisten, maka peneliti ingin membuktikan secara empiris pengaruh ukuran perusahaan, pertumbuhan penjualan dan risiko bisnis pada struktur modal di industri otomotif Indonesia. Konsep Trade off dalam balancing theory adalah menyeimbangkan manfaat dan biaya dari penggunaan utang dalam struktur modal sehingga disebut pula sebagai trade off theory. Berdasarkan Modigliani dan Miller (2004) semakin besar utang yang digunakan, semakin tinggi nilai perusahaan. Struktur modal yang optimal adalah keseimbangan antara manfaat dan biaya dari pendanaan dengan utang (Brigham dan Houston, 2011). Teori Trade Off menggambarkan bagaimana perusahaan mensubsitusi antara ekuitas dengan utang atau utang dengan ekuitas. Proposi penggunaan ekuitas dengan utang yang optimal diharapkan mampu mengoptimalkan nilai perusahaan juga. Apabila penggunaan utang telah melewati batas optimal maka setiap penambahan utang akan menurunkan nilai perusahaan. Hal ini dikarenakan utang yang digunakan perusahaan untuk mencapai nilai perusahaan yang optimal mempunyai manfaat lebih tinggi dibandingkan dengan biaya yang akan dikeluarkan perusahaan.

Implikasi pecking order theory adalah perusahaan menetapkan kebijakan prioritas sumber dana (Laili Hidayati, et al, 2013). Pecking order theory menjelaskan mengapa perushaan-perusahaan yang profitable (menguntungkan) umumnya meminjam dalam jumlah yang sedikit. Penggunaan dana eksternal dalam utang lebih diutamakan daripada modal sendiri. Isu yang dihadapi para 
manajer keuangan yaitu hubungan antara struktur modal dengan nilai perusahaan. Menurut Martono dan Harjito (2011), struktur modal merupakan perbandingan pendanaan jangka panjang dengan modal sendiri. Menurut Husnan (2000), teori struktur modal ingin menjelaskan ada tidaknya pengaruh perubahan struktur modal terhadap nilai perusahaan.

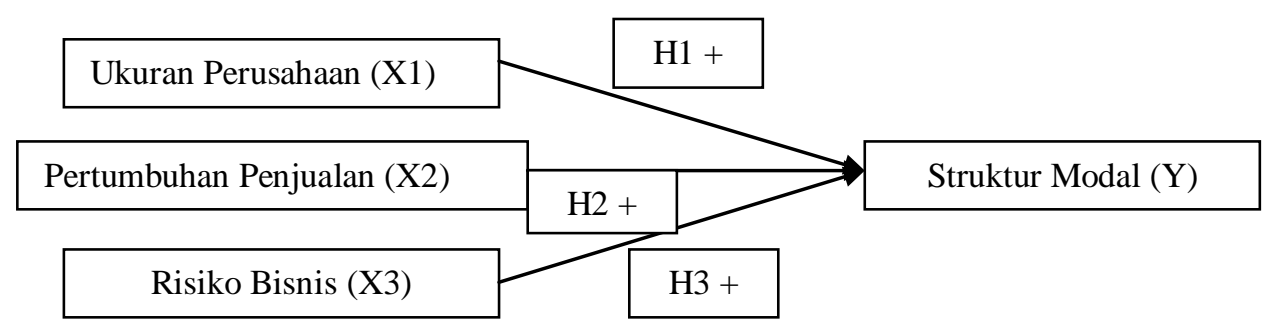

\section{Gambar 1. Kerangka konseptual}

Ukuran perusahaan, faktor yang dikiranya dapat mempengaruhi perusahaan dalam menentukan seberapa besar kebijakan atau keputusan pendanaan dalam memenuhi aset perusahaan.(Rafiq et al., 2008). Perusahaan besar juga memiliki kemungkinan kebangkrutan yang lebih rendah daripada perusahaan kecil, sehingga menurut trade off theory, semakin besar perusahaan maka perusahaan dapat menggunakan utang lebih banyak berhubung dengan rendahnya risiko perusahaan besar (Furi dan Saifudin, 2012). Berdasarkan uraian tersebut, maka penelitian ini mengajukan hipotesis sebagai berikut :

$\mathrm{H}_{1} \quad$ : Semakin tinggi Ukuran Perusahaan maka semakin tinggi Struktur Modal Perusahaan.

Peningkatan pertumbuhan penjualan menyebabkan perusahaan diperlukannya peningkatan modal untuk mendorong pengembangan perusahaan. Hal ini sesuai dengan pecking order theory mengungkapkan bahwa perusahaan yang memiliki pertumbuhan penjualan yang meningkat setiap tahunnya 
dikarenakan perputaran pendapatan yang tinggi, hal inilah yang dapat mempengaruhi perusahaan mampu menggunakan dana internal untuk kegiatan operasional sehingga (Mahardhika dan Aisjah, 2014:8). Pertumbuhan penjualan menurut Amidu (2007) berpengaruh positif terhadap nilai perusahaan. Pertumbuhan penjualan yang tinggi akan mampu meningkatkan penilian investor terhadap perusahaan dan pada akhirnya struktur modal perusahaan ikut meningkat. Berdasarkan uraian diatas, maka penelitian ini mengajukan hipotesis sebagai berikut :

$\mathrm{H}_{2} \quad$ :Semakin tinggi Pertumbuhan Penjualan maka semakin tinggi Struktur Modal Perusahaan

Risiko bisnis merupakan risiko dasar yang dimiliki perusahaan selain risiko keuangan sebagai tambahan risiko perusahaan akibat penggunaanutang. Didasari oleh trade off theory, perusahaan dengan probabilitas yang tinggi secara tidak langsung mempunyai risiko bisnis yang besar dan akan melakukan usaha untuk mengurangi pajaknya melalui meningkatkan rasio utangnya, maka peningkatan utang tersebut akan mengurangi pajak (Sudana, 2011). Joni dan Lina (2012), memberikan bukti risiko bisnis tidak mempengaruhi struktur modal sesuai dengan penelitian yang dilakukan oleh Indraya (2012), yang memberikan bukti risiko bisnis tidak mempengaruhi struktur modal, menurut Prabasari dan Kusuma (2005) menunjukan bahwa risiko bisnis mempengaruh secara negatif pada struktur modal perusahaan. Berdasarkan uraian diatas, maka penelitian ini mengajukan hipotesis sebagai berikut :

$\mathrm{H}_{3}$ : Semakin tinggi Risiko bisnis maka semakin tinggi Struktur Modal Perusahaan 


\section{METODE PENELITIAN}

Penelitian ini menggunakan metode kuantitatif yang berbentuk asosiatif. Sugiyono (2014:45) penelitian asosiatif merupakan jenis penelitian yang menjelaskan pengaruh variabel bebas terhadap variabel terikat. Lokasi penelitian ini dilakukan pada perusahaan otomotif yang terdaftar di Bursa Efek Indonesia (BEI) dari tahun 2014-2016 yang diakses melalui alamat website www.idx.co.id. Obyek penelitian ini adalah struktur modal perusahaan di perusahaan otomotif yang tercantum di Bursa Efek Indonesia (BEI) periode 2014-2016. Dalam penelitian ini struktur modal perusahaan dapat dihitung dengan membandingkan total utang dengan modal sendiri di perusahaan otomotif yang tercantum di Bursa Efek Indonesia (BEI) periode 2014-2016. Di proksikan DER (Debt to Equity Ratio). Ukuran perusahaan proksinya adalah Total Aktiva yaitu rasio yang melihat jumlah aset dan penjualan pada perusahaan otomotif yang terdaftar di BEI periode 2014-2016. Pertumbuhan penjualan dalam penelitian ini digambarkan melalui total penjualan tahun sebelumnya dan tahun sekarang perusahaan pada perusahaan otomotif di BEI tahun 2014-2016. Risiko Bisnis dalam penelitian ini digambarkan melalui total laba bersih sebelum pajak dibandingkan dengan total aset perusahaan pada perusahaan otomotif di BEI tahun 2014-2016.

Populasi dari penelitian ini adalah 13 perusahaan otomotif dan sampel dari penelitian ini adalah 12 perusahaan otomotif yang terdaftar di Bursa Efek Indonesia dari periode 2014-2016. Sampel dari populasi menggunakan metode purposive sampling. Purposive sampling adalah metode penentuan sampel dengan pertimbangan tertentu (Sugiyono, 2014:122). Adapun pertimbangan atau kriteria- 
kriteria sampel yang digunakan pada penelitian ini : Perusahaan otomotif yang terdaftar di BEI selama tahun 2014-2016, tidak mengalami delisting, dan Perusahaan otomotif yang terdfatar di BEI dan menerbitkan laporan keuangan berturut-turut pada tahun 2014-2016.

Metode dalam pengolahan data digunakan oleh penelitian ini adalah metode observasi nonpartisipan yaitu metode pengolahan data dengan melakukan observasi dimana peneliti tidak terlibat dari fenomena yang diamati dan hanya bertindak sebagai pengawas (Sugiyono, 2014:204).Jenis data yang digunakan dalam penelitian in adalah data kuantitatif, dan sumber data dalam penelitian ini adalah data sekunder. Teknik analisis data yang digunakan adala uji Analisis Linier Berganda. Model regresi yang baik adalah model regresi yang memenuhi asumsi-asumsi metode kuadrat tekecil yang disebut asumsi klasik, oleh karena itu uji asumsi klasik dilakukan sebelum menguji Analisis Linier Berganda.

\section{HASIL DAN PEMBAHASAN}

Hasil dari statistik deskriptif menggambarkan mengenai karakteristik variabelvariabel yang diteliti seperti jumlah amatan, nilai minimu, nilai maksimum, nilai rata-rata (mean) dan standar deviasi. Nilai minimum merupakan nilai yang terendah dari masing-masing variabel. Nilai maksimum adalah nilai tertinggi dari masing-masing variabel. Nilai rata-rata (mean) merupakan nilai rata hitung dari suatu data. Standar deviasi adalah perbedaan nilai data yang diteliti dengan nilai rata-ratanya. 


\section{Tabel 3.}

\section{Nama Perusahaan Sampel}

\begin{tabular}{lll}
\hline No. & Kode & Nama Perusahaan \\
\hline 1. & ASII & PT. Asra Internasional \\
2. & AUTO & PT. Astra Autopart \\
3. & BRAM & PT. Indo Kordsa \\
4. & GDYR & PT. Goodyear Indonesia \\
5. & GJTL & PT. Gajah Tunggal \\
6. & IMAS & PT. Indomobil Sukses Internasional \\
7. & INDS & PT. Indospring \\
8. & LPIN & PT. Multi Prima Sejahtera \\
9. & MASA & PT. Multistrada Arah Sarana \\
10. & NIPS & PT. Nipress \\
11. & PRAS & PT. Prima Alloy Steel Universal \\
12. & SMSM & PT. Selamat Sempurna
\end{tabular}

Sumber: Data diolah, 2018

Tabel 4.

Statistik Deskriptif Penelitian

\begin{tabular}{llllll}
\hline & N & Minimum & Maximum & Mean & Std. Deviation \\
\hline UP & 36 & 25,92 & 33,20 & 29,2439 & 1,71658 \\
TP & 36 &,- 30 &, 82 &, 0544 &, 18746 \\
BRISK & 36 &,- 20 &, 31 &, 0461 &, 09069 \\
DER & 36 &, 20 & 8,26 & 1,2636 & 1,39423 \\
\hline
\end{tabular}

Valid N (listwise) $\quad 36$

Sumber: Data diolah, 2018

Tabel 4 menunjukkan pengujian statistik deskriptif dapat dijelaskan sebagai berikut, Variabel nilai perusahaan (Y) diproksikan dengan DER. hasil analisis statistik deskriptif memberikan nilai minimum DER sebesar 0.20 dan nilai maksimum sebesar 8,26. Nilai rata-rata sebesar 1,2636 yang berarti dari 36 sampel amatan perusahaan otomotif yang terdaftar di BEI tahun 2014-2016 mempunyai nilai rata-rata struktur modal sebesar 1,2636. Standar deviasinya 1,39423 menunjukan bahwa adanya penyimpangan terhadap nilai rata-rata sebesar 1,2636. Variabel Ukuran perusahaan diproksikan dengan total aset. Hasil statistik 
deskriptif ukuran perusahaan memberikan nilai minimum sebesar 25,92 dan nilai maksimum sebesar 33,20. Nilai rata-rata sebesar 29,2439 yang berarti dari 36 sampel amatan perusahaan otomotif yang terdaftar di BEI tahun 2014-2016 mempunyai nilai rata-rata ukuran perusahaan sebesar 29,2439. Standar deviasi sebesar 1,71658 menunjukkan bahwa adanya penyimpangan pada nilai rata-rata sebesar 29,2439. Variabel Pertumbuhan penjualan memberikan nilai minimum sebesar -0,30 dan nilai maksimum sebesar 0,82 . Nilai rata-rata sebesar 0,0544 memiliki arti bahwa dari 36 sampel amatan perusahaan otomotif yang terdaftar di BEI tahun 2014-2016 mempunyai nilai rata-rata pertumbuhan penjualan sebesar 0,0544. Standar deviasi sebesar 0,18746 memberikan arti bahwa adanya penyimpangan pada nilai rata-rata sebesar 0,0544. Variabel Risiko bisnis diproksikan dengan business risk (BRISK) menunjukkan nilai minimum sebesar 0,20 dan nilai maksimum sebesar 0,31 . Nilai rata-rata sebesar 0,0461 memiliki arti bahwa dari 36 sampel perusahaan otomotif yang terdaftar di BEI tahun 2014-2016 mempunyai nilai rata-rata risiko bisnis sebesar 0,0461. Standar deviasi sebesar 0,09069 memiliki arti bahwa adanya penyimpangan pada nilai rata-rata sebesar 0,0461 .

Uji normalitas bertujuan untuk menguji apakah residual atau variabel pengganggu dalam model regresi berdistribusi normal.Uji normalitas dilakukan dengan uji non-statistik parametrik Kolomogoro-Smirnov (K-S). Nilai Asymp. Sig (2-tailed) dari model persamaan yang diuji sebesar 0,521 lebih besar dari tingkat alpha, $\alpha=0,05$. Hal ini membuktikan bahwa data yang digunakan dalam penelitian ini berdistribusi normal. Dapat dilihat melalui tabel 5 berikut ini. 
Tabel 5.

Uji Normalitas

\begin{tabular}{lll}
\hline & & Undtandardized Residual \\
\hline $\mathrm{N}$ & & 36 \\
Normal Parameters $^{\text {a.b }}$ & Mean &, 0000000 \\
& Std. Deviation &, 88272901 \\
Most Extreme & Absolute &, 136 \\
Differences & Positive &, 136 \\
& Negative &,- 067 \\
Kolomogorov-Smirnov Z & &, 815 \\
Asymp. Sig. (2-tailed) & &, 521 \\
\hline \multicolumn{2}{c}{ Sumber: Data diolah, 2018 } &
\end{tabular}

Uji autokorelasi menunjukkan menguji pada model regresi terdapat korelasi pada kesalahan pengganggu pada periode $\mathrm{t}$ dan kesalahan pengganggu pada periode t-1 (sebelumnya) (Ghozali, 2016:107). Model regresi yang baik yaitu model regresi yang tidak mengandung gejala autokorelasi. Nilai dw yang dihasilkan 1,464 dikarena jumlah $\mathrm{n}=36$ dan $\mathrm{k}=1$, diperoleh nilai $\mathrm{d}_{\mathrm{L}}=1,2953$ dan $\mathrm{d}_{\mathrm{U}}=1,6539$ sehingga diperoleh juga nilai $4-\mathrm{d}_{\mathrm{U}}=2,3461$ maka dapat dirumuskan $\mathrm{d}_{\mathrm{L}}<\mathrm{dw}<\left(4-\mathrm{d}_{\mathrm{U}}\right)$ yaitu $(1,2953<1,464<2,3461)$. Hal ini menunjukkan data yang digunakan bebas dari autokorelasi. Dapat dilihat melalui tabel 6 berikut ini.

Tabel 6.

Uji Autokorelasi

\begin{tabular}{llllll}
\hline Model & $\mathbf{R}$ & R Square & $\begin{array}{l}\text { Adjusted R } \\
\text { Square }\end{array}$ & $\begin{array}{l}\text { Std. Error of } \\
\text { the Estimate }\end{array}$ & $\begin{array}{l}\text { Durbin- } \\
\text { Watson }\end{array}$ \\
\hline 1 &, $774^{\text {a }}$ &, 559 &, 562 &, 92318 & 1,464 \\
\hline Sumber: Data diolah, 2018 & & & &
\end{tabular}

Uji Multikolinieritas bertujuan untuk mengetahui hubungan anatara variabel bebas. Uji multikolinieritas dapat dilihat melalui nilai tolerance dan VIF. Jika nilai tolerance maupun nilai VIF mendekati angka satu, maka antara variabel bebas tidak terjadi multikolinieritas adalah nilai tolerance $\geq 10 \%$ dan nilai VIF $\leq$ 10\%, sehingga hal ini memiliki arti bahwa model persamaan regresi yang 
digunakan bebas dari gejala multikolinearitas. Dapat dilihat melalui tabel 6 berikut ini:

Tabel 7.

Uji Multikolinieritas

\begin{tabular}{lccl}
\hline \multirow{2}{*}{ Variabel } & \multicolumn{2}{c}{ Collinearity Statistics } & Kesimpulan \\
\cline { 2 - 3 } & Tollerance & VIF & \\
\hline SIZE & 0,958 & 1,044 & Tidak terjadi multikolinieritas \\
SG & 0,950 & 1,053 & Tidak terjadi multikolinieritas \\
BRISK & 0,949 & 1,054 & Tidak terjadi multikolinieritas \\
\hline
\end{tabular}

Sumber: Data diolah, 2018

Uji Heteroskedastisitas digunakan untuk menguji pada model regresi terjadi ketidaksamaan variance dari residual satu pengamatan ke pengamatan lain (Utama, 2014). Nilai signfikan pada variabel ukuran perusahaan sebesar 0,413, nilai signifikan pada variabel pertumbuhan penjualan sebesar 0,660 , dan nilai signifikan pada variabel risiko bisnis adalah sebesar 0,900. Oleh karena ini dapat disimpulkan tingkat signifikansi ketiga variabel lebih besar dari 0,05 yang berarti bahwa model regresi yang dianalisis tidak mengandung heteroskedastisitas. Dapat dilihat dari tabel 7 berikut ini:

Tabel 8.

Uji Heteroskedastisitas

\begin{tabular}{|c|c|c|c|c|c|c|}
\hline & \multirow{2}{*}{ Model } & \multicolumn{2}{|c|}{$\begin{array}{l}\text { Unstandardized } \\
\text { Coefficients }\end{array}$} & \multirow[t]{2}{*}{$\begin{array}{l}\text { Standardized } \\
\text { Coefficients }\end{array}$} & \multirow[b]{2}{*}{$\mathbf{T}$} & \multirow[b]{2}{*}{ Sig. } \\
\hline & & B & $\begin{array}{l}\text { Std. } \\
\text { Error }\end{array}$ & & & \\
\hline \multirow[t]{4}{*}{1} & (Constant) & 1,323 & 1,594 & & ,830 & ,413 \\
\hline & SIZE &,- 024 &, 054 &,- 075 &,- 444 & ,660 \\
\hline & SG & 1,051 &, 501 & ,343 & 2,027 & ,051 \\
\hline & BRISK & ,132 & 1,036 &, 022 & , 127 & ,900 \\
\hline
\end{tabular}

Sumber: Data diolah, 2018 
Analisis Regresi Linier Berganda merupakan teknik analisis penelitian yang memiliki tujuan untuk membuktikan kemampuan ukuran perusahaan, pertumbuhan penjualan dan risiko bisnis mempengaruhi struktur modal perusahaan. Hasil pengolahan Analisis Regresi Linier Berganda disajikan dalam Tabel 4 sebagai berikut:

Tabel 9.

Analisis Regresi Linier Berganda

\begin{tabular}{lllllll}
\hline \multirow{2}{*}{ Model } & \multicolumn{2}{l}{$\begin{array}{l}\text { Unstandardized } \\
\text { Coefficients }\end{array}$} & \multicolumn{3}{l}{$\begin{array}{l}\text { Standardized } \\
\text { Coefficients }\end{array}$} & \\
\cline { 3 - 5 } & B & Std. Error & Beta & T & Sig. \\
\hline 1 & (Constant) &,- 565 & 2,718 & &,- 208 &, 837 \\
& UP &, 066 &, 093 &, 081 &, 711 &, 482 \\
& TP & 4,135 &, 854 &, 556 & 4,840 &, 000 \\
& BRISK & $-7,132$ & 1,766 &,- 464 & $-4,037$ &, 000 \\
\hline
\end{tabular}

Sumber: Data diolah, 2018

Berdasarkan hasil Uji Regresi liniear pada Tabel 9 maka diperoleh persamaan sebagai berikut:

$$
\mathrm{Y}=-0,565+0,066\left(\mathrm{X}_{1}\right)+4,135\left(\mathrm{X}_{2}\right)-7,132\left(\mathrm{X}_{3}\right)+\mathrm{e}
$$

Berdasarkan persamaan di atas, dapat dijelaskan hal-hal sebagai berikut: Nilai konstanta $(\alpha)$ sebesar $-0,565$ memiliki arti apabila variabel independen konstan sebesar 0, maka variabel terikat yaitu struktur modal (Y) yang diproksikan dengan DER tidak sama dengan 0 . Nilai koefisien regresi $\left(\beta_{1}\right)$ dari ukuran perusahaan $\left(\mathrm{X}_{1}\right)$ sebesar 0,066 memiliki arti jika ukuran perusahaan yang dilihat dari total aset, maka struktur modal (Y) yang diproksikan dengan DER meningkat sebesar 0,066 satuan, dengan asumsi variabel lainnya tidak terjadi perubahan. 
Nilai koefisien regresi $\left(\beta_{2}\right)$ dari pertumbuhan penjualan $\left(\mathrm{X}_{2}\right)$ sebesar 4,135 memiliki arti jika pertumbuhan penjualan sebesar 4,135 satuan, maka struktur modal (Y) yang diproksikan dengan DER meningkat sebesar 4,135 satuan, dengan asumsi variabel lainnya konstan. Nilai koefisien regresi $\left(\beta_{3}\right)$ dari risiko bisnis sebesar -7,132 memiliki arti jika risiko bisnis diproksikan dengan BRISK, maka struktur modal (Y) yang diproksikan dengan DER menurun sebesar 7,132 satuan, dengan asumsi variabel lainnya konstan.

Berdasarkan hasil pengolahan data kelayakan model (F) bisa dilihat nilai uji F sebesar 15,943 dengan nilai p-value (Sig. F) yakni 0,000 lebih kecil dari nilai $\alpha$ $=0,05$. Hal ini membuktikan model persamaan pada penelitian ini layak untuk digunakan. Uji statistik $\mathrm{t}$ menunjukkan ada atau tidaknya pengaruh masingmasing variabel bebas pada variabel dependennya secara parsial. Pengujian ini dilakukan dengan melihat nilai signifikansi masing-masing variabel dengan $\alpha=$ 0,05. Pada tabel 9 uji regresi linier berganda dapat dijelaskan sebagai berikut, Variabel ukuran perusahaan $\left(\mathrm{X}_{1}\right)$ yang diproksikan dengan debt to equity ratio (DER) memiliki t hitung sebesar 0,711 dengan nilai signifikansi 0,482. Nilai t hitung sebesar 0,711 memiliki nilai positif yang berarti memberikan arah positif pada hipotesis I. Nilai signifikansi sebesar 0,482 lebih besar dari tingkat signifikansi 0,05 , yang mempunyai arti ukuran perusahaan $\left(\mathrm{X}_{1}\right)$ tidak mempengaruhi struktur modal (Y). Hal ini membuktikan ukuran perusahaan $\left(\mathrm{X}_{1}\right)$ tidak mempengaruhi struktur modal $(\mathrm{Y})$, sehingga hipotesis I dalam penelitian ini ditolak. 
Variabel pertumbuhan penjualan memiliki t hitung sebesar 4,840 dengan nilai signifikansi 0,000 . Nilai t hitung sebesar 4,840 memiliki nilai positif yang berarti memberikan arah positif pada hipotesis II. Nilai signifikansi sebesar 0,000 lebih kecil dibandingkan tingkat signifikansi 0,05 yang berarti bahwa pertumbuhan penjualan $\left(\mathrm{X}_{2}\right)$ mampu berpengaruh pada struktur modal $(\mathrm{Y})$ sehingga hipotesis II dalam penelitian ini diterima. Variabel pertumbuhan penjualan memiliki t hitung sebesar $-4,037$ dengan nilai signifikansi 0,000 . Nilai t hitung sebesar 4,037 memiliki nilai negatif yang berarti memberikan arah negatif pada hipotesis III. Nilai signifikansi sebesar 0,000 lebih kecil dibandingkan tingkat signifikansi 0,05 yang berarti bahwa risiko bisnis $\left(\mathrm{X}_{3}\right)$ berpengaruh negatif pada struktur modal (Y) sehingga hipotesis III dalam penelitian ini ditolak.

Berdasarkan hasil uji analisis regresi linier berganda pada Tabel 9. membuktikan bahwa ukuran perusahaan tidak mempengaruhi struktur modal. Hal ini ditunjukkan melalui nilai regresi variabel ukuran perusahaan yang diproksikan SIZE sebesar 0,066 dengan t hitung sebesar 0,711 dan nilai signifikansi sebesar 0,482 yang lebih tinggi dari tingkat signfikansi $(\alpha=0,05)$ sehingga dapat membuktikan bahwa ukuran perusahaan (SIZE) tidak mempengaruhi struktur modal (DER). Hal ini berarti peneliti belum mampu menunjukan hipotesis pertama yang dinyatakan "Semakin tinggi ukuran perusahaan semakin tinggi struktur modal perusahaan"

Hasil penelitian ini tidak sejalan terhadap penelitian sebelumnya yang dilakukan oleh Ristiani dan Hartono (2010) dengan judul “ Analisis pengaruh Dividend Payout Ratio, Kepemilikan Manajerial, Profitabilitas dan Ukuran 
Perusahaan pada keputusan pendanaan". Hasil penelitian membuktikan bahwa ukuran perusahaan mempengaruhi positif pada struktur modal. Tetapi hasil penelitian ini sesuai dengan penelitian Lessy (2016) dengan judul “ Pengaruh Ukuran Perusahaan, Likuiditas, Profiabilitas, dan Struktur Aktiva terhadap Struktur Modal", bahwa ukuran perusahaan tidak berpengaruh positif pada struktur modal.

Tabel 9. menunjukkan bahwa pertumbuhan penjualan berpengaruh pada struktur modal.Hal ini ditunjukkan dengan koefisien regresi variabel pertumbuhan penjualan (SG) sebesar 0,556 dan t hitung sebesar 4,840 dengan nilai signifikansi sebesar 0,000 lebih kecil dibandingkan tingkat signifikansi $(\alpha=0,05)$ yang memiliki arti bahwa H2 diterima. Sehingga dapat disimpulkan pertumbuhan penjualan yang diproksikan dengan Tingkat Penjualan mampu mempengaruhi secara positif pada struktur modal yang artinya semakin meningkat pertumbuhan penjualan semakin meningkatkan struktur modal perusahaan. Hasil penelitian ini sejalan dengan teori pecking order dan penelitian yang dilakukan Bhaduri (2002), Rachmadwrdani (2007), Rista dan Bambang (2011), Kennedy dkk (2013) yang juga menyatakan bahwa pertumbuhan penjualan berpengaruh positif pada struktur modal.

Berdasarkan hasil uji analisis regresi linier berganda pada Tabel 4 menunjukkan risiko bisnis mempengaruhi pada struktur modal.Hal ini ditunjukkan dengan koefisien regresi variabel risiko bisnis (BRISK) sebesar 0,464 dengan t hitung senilai -4,037 dan nilai signifikansi senilai 0,000 lebih kecil dari tingkat signifikansi $(\alpha=0,05)$ memiliki arti bahwa $\mathrm{H}_{2}$ diterima. 
Sehingga dapat disimpulkan risiko bisnis yang diproksikan dengan (Business Risk) mampu mempengaruhi pada struktur modal dan memiliki arah negatif yang artinya semakin rendah risiko bisnis semakin tinggi struktur modal perusahaan.

Hasil penelitian sependapat dengan penelitian yang telah diujikan oleh Murtiningtyas (2012) dimana menjelaskan bahwa risiko bisnis berpengaruh negatif pada kebijakan utang, perusahaan yang memiliki risiko tinggi akan mempengaruhi kreditur dalam mengahadapi risikonya, sesuai dalam Trade-off theory yaitu menyeimbangkan manfaat dan biaya yang timbul akibat penggunaan utang. Sebagai implikasinya, perusahaan dengan risiko bisnis besar harus menggunakan utang lebih rendah dibanding perusahaan yang mempunyai risiko bisnis rendah (Furaida. 2012). Semakin tinggi risiko bisnis, penggunaan utang yang tinggi akan mempersulit perusahaan dalam mengembalikan utang mereka.

\section{SIMPULAN}

Berdasarkan hasil penelitian yang diperoleh melalui pengujian statistik serta pembahasan yang telah dipaparkan pada bab sebelumnya, maka didapatkan simpulan sebagai berikut: Ukuran perusahaan tidak berpengaruh pada struktur modal perusahaan. Pertumbuhan penjualan berpengaruh positif pada struktur modal perusahaan. Risiko bisnis berpengaruh negatif pada struktur modal perusahaan.

Berdasarkan hasil penelitian dan simpulan, maka saran yang dapat diberikan untuk penelitian selanjutnya adalah sebagai berikut. Bagi Perusahaan yang bersangkutan pihak manajeman perusahaan apabila ingin mengambil keputusan dalam pendanaan, diharapkan mempertimbangkan dengan seksama pengaruh- 
pengaruh struktur modal ini. Dalam penelitian ini pertumbuhan penjualan mempengaruhi secara positif dalam menilai struktur modal perusahaan. Manajer keuangan harus mampu untuk melihat dengan teliti faktor yang mempengaruhi struktur modal perusahaan tersebut. Industri otomotif di Indonesia sangatlah penting, karena menjadi salah satu industri terbesar yang mampu mendorong indonesia di kaca Internasional. Selain itu perlu mempertimbangkan ukuran perusahaaan dan risiko bisnis perusahaan dalam pembentukan struktur modal perusahaan itu senditi.

Penelitian ini menggunakan ukuran perusahaan, pertumbuhan penjualan dan risiko bisnis dalam meneliti struktur modal perusahaan. Hasil dari penelitian ini menunjukan Industri Otomotif dalam 3 tahun terakhir berfluktuatif. Diharapkan peneliti selanjutnya juga dapat memperluas objek penelitian dengan cara menambah variabel independen lainnya yang sesuai dengan penelitian, serta menggunakan sampel yang lebih banyak seperti dengan cara menambah tahun pengamatan atau mengganti sektor yang diteliti dengan kriteria-kriteria yang bersangkutan dengan penelitian.

\section{REFRENSI}

Amidu, M. 2007. How Does Dividends Policy Affect Per-formance of The Firm on Ghana Stock Exchange. In-vestment Management and Financial Innovations. Volume 4, Issue 2, 2007.

Awan, Tariq Naeem, Majed Rashid, dan Muhammad Zia-ur-Rehman. 2011. Analysis of The Determinant of Capital Structure in Sugar and Aliied Industry. International Journal of Business and Social Sciences, Vol 2(1): Hal. 221-229.

Bhaduri, Saumitra N, (2002). "Determinants of Corporate Borrowing: Some Evidence from the Indian Corporate Structure", Journal of Economics and Finance, Summer, 26, 2, p. 200. 
Brigham, E.F., Ehrhardt, M.C. (2005), Financial Management Theory AndPractice, Eleventh Edition, South Western Cengage Learning, Ohio.

Brigham, Eugene F. dan Joel F. Houston. 2011. Dasar-dasar ManajemenKeuangan. Edisi 11. Jakarta: Salemba Empat.

Fitri, Santi. 2013. Determinant of Indonesia Firm's Capital Structure Panel Data Analysis. Jurnal Ekonomi dan Bisnis Vol. 18 No. 03. 243-260

Furaida, Yunita Atsni, 2012. Pengaruh Ukuran Perusahaa, Risiko Bisnis dan Profitabilitas Terhadap Struktur Modal Pada Perusahaan Manufaktur yang Terdaftar Di Bursa Efek Indonesia. Jurnal Manajemen Keuangan, Fakultas Ekonomi. Universitas Negeri Semarang.

Indonesia-Investment, 2017 Industri Sektor Otomotif. https://www.investasiinvestment.com. Diakses pada tanggal 25 desember 2017.

Husnan, Suad. 2000. Manajemen Keuangan Teori dan Penerapan (Keputusan Jangka Panjang). Buku 1. Edisi 4. BPFE. Yogyakarta.

Joni dan Lina. 2010. Faktor-faktor yang Mempengaruhi Struktur Modal. JurnalBisnis dan Akuntansi, Vol 12(2): Hal.81-96.

Kartika, Andi. 2009. Faktor-Faktor Yang Mempengaruhi Struktur Modal Pada Perusahaan Manufaktur Yang Go Public Di BEI. Dinamika Keuangan dan Perbankan, Vol 1(2): Hal. 105-122.

Kartini dan Tulus. 2008. Struktur kepemilikan, profitablitas, pertumbuhan aktiva, dan ukuran perusahaan terhadap struktur modal pada perusahaan manufaktur Jurnal Keuangan dan Perbankan, Vol 12, No. 1. Program Studi Keuangan dan Perbankan, Universitas Merdeka Malang.

Kennedy, dkk. 2010. "Faktor-faktor yang Mempengaruhi Struktur Modal pada Perusahaan Real Estate and Property yang Go Public Di Bursa Efek Indonesia”. Jurnal Ekonomi. Universitas Riau.

Laili Hidayati, et al. 2001. "Analisis Faktor-faktor Yang Mempengaruhi Struktur Keuangan Perusahaan Manufaktur Yang Go Public di Indonesia”, Jurnal Bisnis Strategi. Vol.7,Th.V,Juli 2001: 30-48.

Liem, Jemmi Halim. 2013. Faktor-Faktor Yang Mempengaruhi Struktur Modal Pada Industri Consumer Good Yang Terdaftar di BEI Periode 2007-2011. Jurnal Ilmiah Mahasiswa Universitas Surabaya, Vol 2(1): Hal. 1-11

Mahardhika, B.P., dan Aisjah, S. 2014. Pengujian Pecking Order Theory dan Trade Off Theory pada Struktur Modal Perusahaan (Studi pada Perusahaan 
Con-sumer Goods di Bursa Efek Indonesia). Jurnal Ilmiah Mahasiswa FEB.

Martono; Harjito, Agus;. (2011). Manajemen Keuangan. Penerbit EKONISIA, Yogyakarta,2011. , Edisi Kedua, Cetakan Pertama.

Prabansari, Yuke dan Hadri Kusuma. 2005. Faktor-faktor yang Mempengaruhi Struktur Modal Pada Perusahaan Manufaktur Yang Terdaftar Di Bursa Efek Jakarta. Jurnal Sinergi Edisi Khusus On Finance, Hal.1-15.

Rachmawardani, Yulinda (2007). Analisis Pengaruh Aspek Likuiditas, Risiko Bisnis, Profitabilitas dan Pertumbuhan Penjualan Terhadap Struktur Modal Perusahaan. Jurnal Ekonomi Universitas Diponegoro.

Rista Santika dan Bambang Sudiyatno. 2011. Menentukan Struktur Modal Perusahaan Manufaktur di Bursa Efek Indonesia. Dinamika Keuangan dan Perbankan, Nopember 2011, Hal: 172 - 182 Vol. 3, No. 2 ISSN :19794878

Ristiani,danHartono. 2010. Faktor Non Keuangan Pada Opini Going Concern. Jurnal SNA III, Simposium Nasional Akuntansi III Purwokerto 2010. 1-23.

Saidi. 2004. Faktor-faktor yang Mempengaruhi Struktur Modal pada Perusahaan Manufaktur Go Public di BEJ Tahun 1997-2002. Jurnal Bisnis dan Ekonomi. Vol.11,No.1,Maret 2004.

Saleem, Faiza., Bisma Rafique, Qaiser Mehmood, Muhammad Irfan, Rabia Saleem, Sidra Tariq, dan Ghazala Akram. 2013. The Determinant of Capital Structure of Oil and Gas Firms Listed on Karachi Stock Exchange In Pakistan. Interdisciplinary Journal of Contemporary Reaserch In Business, Vol 4(9): Hal. 225-235.

Sudana, I Made., 2010, Manajemen Keuangan Perusahaan Teori dan Praktik, Jakarta: Erlangga

Sugiyono. (2014) Metode Penelitian Kuantitatif Kualitatif dan R\&D. Bandung : Alfabeta

Utama, Made Suyana. 2014. Aplikasi Analisis Kuantitatif Edisi Kedelapan. Denpasar: Fakultas Ekonomi dan Bisnis Universitas Udayana.

Winahyuningsih, Panca., Kertati Sumekar, dan Hanar Prasetyo. 2013. Analisis Faktor-Faktor yang Mempengaruhi Struktur Modal pada Perusahaan Manufaktur yang Go Public di Bursa Efek Indonesia. Jurnal Ekonomi, Hal. 1-17. 
Yuliati, Sri. (2013). Pengujian Pecking Order Theory: Analisis Faktor-faktor yang mempengaruhi Struktur Modal Industry Manufaktur di BEI Periode setelah krisis moneter. E-Journal Politama Vol. 10 No. 1 